\title{
Effect of Ammonium Sulfate Application Levels on the Growth and Yield of IR-28 Rice
}

\author{
Claurence Nkumbe Ndille ${ }^{1 *}$, Michael Amos Ballah ${ }^{2}$, Shafiqullah Safi ${ }^{3}$, Isaac Mupeta ${ }^{4}$ \\ ${ }^{1}$ Institute of Agricultural Research for Development \\ P.M.B.25, Buea, Cameroon \\ ${ }^{2}$ Extension Officer, Ministry of Agriculture (MOA) \\ Republic of Liberia (RL) \\ ${ }^{3}$ General Extension Manager at district Level in Kunar Province \\ Afghanistan \\ ${ }^{4}$ Agricultural Officer, Ministry of Agriculture \\ Crops Section, Republic of Zambia \\ ${ }^{*}$ Corresponding author's email: clarencendille [AT] yahoo.fr
}

\begin{abstract}
The study was conducted in JICA Tsukuba experimental rice field RE-2 from April 2018 to September 2018, to determine the effect of different levels of nitrogen fertilizer (Ammonium sulfate) application, on the growth

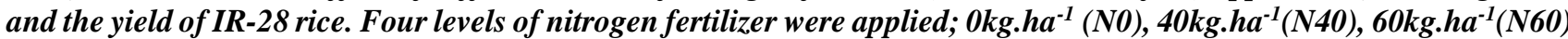
and 80kg.ha-1 (N80). For each of the four levels, part of the fertilizer was applied as basal dressing prior to transplanting, and the rest was applied as top-dressing at the panicle initiation stage. The experimental design was a Randomized Complete Block Design (RCBD) with four treatments and three replications. The plant length, the tiller number and the leaf colour were measured for growth data. The number of panicles per $m^{2}$, the number of spikelets per panicle, the spikelet fertility rate, the 1000 grains weight, and the calculated yield were determined for yield components assessment. The plant length and the tiller number were significantly higher in N80 and N60 compared to N40 and NO, and N80 showed the highest values. There was no significant difference among the four nitrogen levels in terms of the number of panicles per $\mathrm{m}^{2}$ and the number of spikelets per panicle. The spikelet fertility rate and the 1000 grains weight were significantly higher in N80, N60 and N40 compared to N0, and no significant difference was observed among the three.

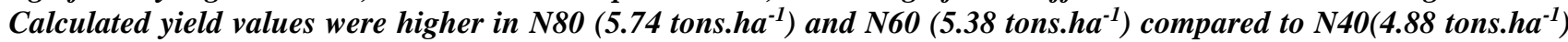
and NO (4.36 tons.h $\left.{ }^{-1}\right)$, but there were no significant differences among the four treatments (5\% Level of HSD). These results suggest that a high yield of rice can be achieved through the application of high amounts of nitrogen fertilizers. N60 nitrogen level can be recommended for optimum yield of IR-28. Although N80 showed higher yield and yield components, N60 is the best and the most economical nitrogen level required for optimum yield of IR-28.
\end{abstract}

Keywords--- Oryza sativa L, Agronomy, Physiology, Nitrogen amount

\section{INTRODUCTION}

Rice (Oryza sativa L.) for many decades was the staple food only for the people in Asia. Nowadays, rice has become the main staple food that provides food calories to people all over the world. The consumption of rice has exponentially increased in the world over the past twenty years. Currently, it is reported that more than half of the world population eats rice as a staple food (Muthayya et al.,2014). The world's population is estimated to reach 9 billion people by 2050. Considering the major role rice is now playing in people's nutrition across the world, rice production must increase by at least $50 \%$ to be able to feed the world population (FAO, 2008). There are two main ways through which rice production can be increased in the world; expansion of rice cultivation lands and increase in the yield of rice per unit area (Tang et al., 2017). The best way rice production can be increased in a sustainable manner nowadays is by increasing the yield of rice per unit area. An increase in rice yield of at least $1 \%$ is needed every year to meet the increasing global demand for rice (Normile, 2008).

Numerous yield improvement practices have been developed in the past decades. Some of these practices are the use of high yielding varieties, irrigation, planting density, seedling age, and the use of fertilizers. The use of fertilizers is the most widely adopted practice, and the most efficient also. Nitrogen fertilizers are the main fertilizers used in rice cultivation. In Asia, the number one producer of rice in the world, reports have shown that the high yield levels of rice grains achieved currently is because of excessive use of nitrogen (N) fertilizers (Ladha \& Reddy, 2003; Samonte et al., 2006). In China, 
the use of high amounts of nitrogen fertilizers is reported to have become a common practice for agricultural production (Gong et al, 2011; Ju et al., 2015; Tian et al., 2016). Nitrogen fertilizers are widely used because, of all the nutrient elements that are required for plant growth and development, nitrogen is the most important and often the main limiting factor for adequate growth and development of plants (Kant, 2018). Nitrogen $(\mathrm{N})$ has a determining role in crop production because and is a key component in the biomass accumulation process (Salvagiotti \& Miralles, 2008). Nitrogen constitutes a building block for plant protoplasm and acts as a catalyst for other nutrients. Nitrogen is also reported to be the most active factor that determines soil fertility (Agreen, 1985; Cassman et al.,2002). Studies have reported that rice yield is significantly increased when nitrogen fertilizers are applied during its cultivation (Cassman et al.,2002; Guo et al., 2010). Nitrogen is a key element in the rice grain filling process that determines grains yield and quality (Gregersen et al.,2008). The amount of nitrogen fertilizer to be applied during rice cultivation however remains ambiguous. Some studies have reported that the use of high amounts of nitrogen $(\mathrm{N})$ fertilizer application is a conventional method used to increase rice yield (Zhang et al.,2015; Zheng et al., 2016). Other studies reported that high amounts of nitrogen fertilizer application could cause the plant to lodge and decrease the rice yield in a very significant way. Also, it is reported that excessive nitrogen fertilizer application during rice cultivation significantly reduces rice quality (Zhu et al., 2017; Carley et al.,2009). Furthermore, applying high amounts of nitrogen fertilizer in an unchecked manner is detrimental to the rice plant and to the environment (Guo et al., 2010; La Croix et al., 2005; Liu et al., 2013; Tan et al., 2011).

In addition, although Nitrogen is important for rice plant, if it is applied in high amounts, it may modify the soil productivity by altering microbial communities (Xun et al., 2016). Also, a significant positive correlation has been reported to exist between nitrogen leaching and the rate of nitrogen applied (Li et al., 2007). Some studies have further reported that increasing the amount of nitrogen fertilizer application, does not increase the grain yield (Huang et al., 2007; Yan et al., 2009). Nitrogen Use Efficiency (NUE) is low in rice plant as the plant uses 20-30\% of the applied nitrogen fertilizer (Peng et al.,2006). Thus, applying nitrogen fertilizer at the appropriate amounts could improve rice NUE and yield. Previous studies have revealed that morphological mechanisms of rice yield increase in response to optimized nitrogen $(\mathrm{N})$ management (Zhou et al., 2017). NUE depends largely in the nitrogen management practices especially the amount of nitrogen fertilizer applied (Ju et al., 2009; Yan et al.,2009; Peng et al.,2006). It was reported that, to enhance NUE in rice, $\mathrm{N}$ fertilizer application should be reduced during the mid-tillering stage and increased at the time of panicle initiation stage (Zhong et al., 2007; Yan et al.,2009; Zhang et al. 2013). This experiment was conducted to determine the effect of different amounts of Nitrogen fertilizer applications on the growth and yield of IR-28 (Indica variety).

\subsection{Study site}

\section{MATERIALS AND METHODS}

The research was conducted at the rice experimental field RE-2 of Japan International Cooperation Agency Tsukuba in Japan. The City of Tsukuba also known as "Tsukuba Science City" is located at $36^{\circ} 12$ ' N Latitude, $140{ }^{\circ} 0559$ longitude and at 33 m altitude. The work was conducted from April 2018 to October 2018.

\subsection{Nursery Preparation and Management}

An Indica type rice (Oryza sativa L.) genotype $I R-28$ was used for this experiment. Rice seed was selected using a salt solution of 1.13 specific gravity determined with a hydrometer. Selected seeds were disinfected by soaking them into a mixture of Benlate- T (Thiram-benomyl mixt) fungicide at $0.5 \%$ of 100 grams with 20 litres of water for 24 hours. About 600 grams of treated seed were then soaked into a running water machine at $17{ }^{\circ} \mathrm{C}$ for six to seven days for pre-germination. Pre-germinated seeds were then sowed into nursery boxes of $60 \mathrm{~cm} \times 30 \mathrm{~cm}$ dimensions containing soil, and at the rate of $50 \mathrm{~g}$ of pre-germinated seed per box. After the seeds were sowed, the nursery boxes were placed in a greenhouse to raise rice seedlings. The nursery was monitored at least twice a day to control water supply, diseases, insects, and to measure and record the temperature inside the greenhouse.

\subsection{Land Preparation}

The experimental field RE-2 of $422 \mathrm{~m}^{2}$ (28.7 m x $14.7 \mathrm{~m}$ ) dimension was ploughed using a tractor. A power tiller machine was used for a second tilling to loosen the soil before flooding the field. Samples of soil were collected for chemical analysis JICA Tsukuba Soil laboratory. Soil samples were analyzed, and total carbon content, total nitrogen content, available phosphorous, exchangeable potassium and $\mathrm{pH}$ were determined (table1). After flooding the field, plot layout and fencing were done, and basal fertilization was applied. After basal fertilization, puddling was conducted in each of the spit plot using a small puddling machine. 
Table 1. Chemical composition of the soil of the experimental field (RE-2).

\begin{tabular}{ccccc}
\hline $\begin{array}{c}\text { Total C } \\
\left(\mathbf{g . k g}^{-1}\right)\end{array}$ & $\begin{array}{c}\text { Total N } \\
\left(\mathbf{g . k g}^{-1}\right)\end{array}$ & $\begin{array}{c}\text { Available P (Bray2) } \\
(\mathbf{m g . k g})\end{array}$ & $\begin{array}{c}\text { Exchangeable K } \\
\left.\mathbf{c m o l}^{-1}\right) . \mathbf{k g}^{-1}\end{array}$ & $\begin{array}{c}\mathbf{p H} \\
\left(\mathbf{H}_{2} \mathbf{O}\right)\end{array}$ \\
\hline $\mathbf{1 4 . 1}$ & 1.2 & 83.2 & 0.335 & 6.2 \\
\hline
\end{tabular}

\subsection{Transplanting}

Seedlings at the age of 30 days were manually transplanted. Transplanting was done in straight lines at a density of $30 \mathrm{~cm} x$ $15 \mathrm{~cm} ; 30 \mathrm{~cm}$ between the lines and $15 \mathrm{~cm}$ inside the lines. The plant density was 22.22 hills per $\mathrm{m}^{2}$. Before transplanting, seedlings were treated with a systemic fungicide to prevent and combat fungal diseases that may arise during cultivation. Transplanted seedlings had a plant age in leave number of 4.3 , and a plant length of $17.4 \mathrm{~cm}$.

\subsection{Fertilization}

Basal fertilization was done prior to puddling by application of granular fertilizers containing Nitrogen, Phosphorus and Potassium, on all the plots. Phosphoric acid, chemically known as Phosphorus Pentoxide $\left(\mathrm{P}_{2} \mathrm{O}_{5}\right)$ was applied at the rate of $100 \mathrm{Kg} \mathrm{ha}^{-1}$, to supply Phosphorus to the soil. Potassium Oxide $\left(\mathrm{K}_{2} \mathrm{O}\right)$ also known as Potash, was applied at the basal at the rate of $100 \mathrm{Kg} \mathrm{ha}^{-1}$ at the basal. Phosphoric acid and Potassium Oxide were applied only at the basal and the amounts were the same for all the plots. Four levels of nitrogen fertilizer (Ammonium Sulfate) amount was applied during this experiment; N0, N40, N60, and N80. Ammonium Sulfate fertilization was done in two applications and at two different stages. The first application was done at basal prior to puddling, and the second application was done as top dressing at the panicle initiation stage (Table 2).

\section{Experimental design}

A Randomized Complete Block Design (RCBD) with six treatments and three replications were used for this experiment. The experimental field was divided into 18 spit plots, each of which had a dimension of $4 \mathrm{~m} \times 3.42 \mathrm{~m}$.

Table 2. Nitrogen fertilizer applications levels

\begin{tabular}{llll}
\hline \multirow{2}{*}{ Label } & \multicolumn{2}{l}{ Nitrogen Amount $\left(\mathbf{k g ~ h a} \mathbf{~}^{-\mathbf{1}}\right)$} & \multirow{2}{*}{ Total $\left(\mathbf{k g ~ h a} \mathbf{~ h a}^{-\mathbf{1}}\right)$} \\
\cline { 2 - 3 } & Basal (prior to puddling) & Top dressing $(\mathrm{PI})$ & 0 \\
\hline N0 & 0 & 0 & 40 \\
\hline N40 & 20 & 20 & 60 \\
\hline N60 & 25 & 35 & 80 \\
\hline N80 & 35 & 45 & \\
\hline
\end{tabular}

\subsection{Data Collection}

\section{Growth data}

The first data were collected seven days after transplanting and continued weekly until harvest. Growth data were collected from 6 hills per plot. Three growth parameters were determined during this experiment. Plant length was measured weekly using a meter ruler. The length of the plant was measured from the base of the stem (hill) to the tip of the tallest leaf. The number of tillers per hill was counted and recorded manually once a week. The colour of the leaves was determined using a Leaf Color Chart (LCC), an instrument that is commonly used in the determination of rice leaves greenness, and which indicates the nitrogen content in the leaves.

\section{Determination of yield components}

The number of panicles per $1 \mathrm{~m}^{2}$ was determined by counting the total number of panicles and the number of sterile panicles of 10 hills at three different survey points in the sample field and then deducting the number of sterile panicles from the total number of panicles. The value obtained after the deduction represented the number of fertile panicles. To determine the number of spikelets per panicle, we started by counting the number of spikelets of a total of 10 hills collected from three separate survey points. Three hills were collected from the first point, four hills from the second point, and three hills from the third point. At each survey point, the number of spikelets of the highest panicle and second-lowest panicle of the hills were counted and the average number of spikelets per panicle was calculated. The number of spikelets per $1 \mathrm{~m}^{2}$ was calculated by multiplying the number of spikelets per panicle by the number of fertile panicles per $1 \mathrm{~m}^{2}$. The determination 
of the filled grain percentage or ripening ratio was obtained from the ratio of the number of filled grains to the total number of spikelets. To separate filled grains from unfilled grains, water of 1.0 specific gravity was used. 1000-grains weight was obtained and adjusted to $14 \%$ moisture content. Data on the culm length, panicle length, and internode length were later collected for other yield-related analyses.

\section{Data Analysis}

Microsoft Excel 2013 for Windows was used for data processing and statistical analyses were done using analysis of variance (ANOVA). Differences among means were separated by Fisher's least significant difference (LSD) test and Tukey's HSD Least Significance Difference test at the 0.05 probability level $(p<0.05)$. Microsoft Excel 2013 for windows was used to produce tables and graphs, and all error bars indicated standard errors of means.

\subsection{Growth parameters \\ 3.1.1.Plant length}

The data of the plant length of IR-28 rice in response to four nitrogen fertilizer (Ammonium Sulfate) application amounts are shown in Table 3. N60 and N80 significantly increased the plant length compared to the N0 and N40. Although plant length in N80 appeared to be slightly higher compared to N60, there was no significant difference between the two treatments. The lowest values of plant length were observed in the control treatment N0 (Figure 1).

\subsubsection{Tiller number}

The data of the number of tillers per hill of IR-28 rice in response to four nitrogen fertilizer application amounts is shown in Table 4. From the time of transplanting till the maximum tillering stage, the tiller number was significantly increased by N80 and N60 compared to other treatments (Figure 2). The lowest number of tillers per hill were observed in the control treatment N0 (Table 4).

\subsubsection{Leaf color}

The data presented in Table 5 represent the changes in leaf color of rice plant in response to four nitrogen fertilizer application amounts. The leaf color was significantly increased by N40, N60 and N80 compared to the control N0. However, a decrease in leaf color was observed in all the treatments, from the beginning of active tillering until the time of top-dressing application (Figure 3).

\subsection{Yield components}

The yield components of IR-28 rice in response to four amount of nitrogen fertilizer applications are shown in Table 5. Although the highest number of panicles per $\mathrm{m}^{2}$ was observed in N80, there was no significant difference among the four treatments at a $5 \%$ level of significant difference. The number of spikelets per panicle showed an increasing trend within the treatments as the nitrogen application was increased, but there was no significant difference between the four treatments. N80 and N60 showed higher values of calculated yield values (Table 5), but there was no significant difference between the four treatments at a $5 \%$ level of significant difference. The spikelet fertility rate (Figure 4) and 1000 grains weight (Figure 5) were significantly increased in N80, N60 and N40 compared to N0. 
Table 3: Plant height $(\mathrm{cm})$ of IR-28 rice as influenced by different levels of Nitrogen $(\mathrm{N})$ fertilizer application.

\begin{tabular}{|c|c|c|c|c|c|c|c|c|c|c|c|c|c|c|c|c|c|c|c|c|c|c|}
\hline $\begin{array}{c}\text { Plant } \\
\text { Length }\end{array}$ & 17DAT & & 24DAT & & 31DAT & & $\begin{array}{c}\text { 38DA } \\
T\end{array}$ & & $\begin{array}{l}\text { 46DA } \\
T\end{array}$ & & $\begin{array}{c}\text { 52DA } \\
T\end{array}$ & & $\begin{array}{c}\text { 59DA } \\
T\end{array}$ & & $\begin{array}{c}\text { 66DA } \\
T\end{array}$ & & $\begin{array}{c}\text { 73DA } \\
T\end{array}$ & & $\begin{array}{c}\text { 79DA } \\
T\end{array}$ & & $\begin{array}{c}\text { 87DA } \\
T\end{array}$ & \\
\hline No & 30.4 & $\mathrm{~b}$ & 32.3 & $\mathrm{c}$ & 34.8 & $\mathrm{~b}$ & 37.1 & $\mathrm{c}$ & 40.9 & $\mathrm{~b}$ & 45.4 & $\mathrm{~b}$ & 50.2 & $\mathrm{~b}$ & 55.7 & $\mathrm{~b}$ & 65.2 & $\mathrm{c}$ & 73.6 & $\mathrm{c}$ & 87.0 & $\mathrm{~b}$ \\
\hline N40 & 33.7 & $a b$ & 35.5 & $\mathrm{~b}$ & 38.7 & $\mathrm{a}$ & 41.3 & $\mathrm{~b}$ & 45.4 & $a b$ & 49.1 & $\mathrm{ab}$ & 53.3 & $a b$ & 63.2 & $\mathrm{a}$ & 71.4 & $\mathrm{~b}$ & 87.9 & $\mathrm{~b}$ & 95.3 & a \\
\hline N60 & 34.7 & $\mathrm{a}$ & 36.6 & $\mathrm{~b}$ & 39.5 & $\mathrm{a}$ & 42.9 & $a b$ & 48.1 & $\mathrm{a}$ & 51.8 & $\mathrm{a}$ & 56.2 & $\mathrm{a}$ & 66.6 & $\mathrm{a}$ & 76.8 & $\mathrm{a}$ & 93.4 & $a b$ & 98.4 & $\mathrm{a}$ \\
\hline N80 & 34.5 & $\mathrm{a}$ & 38.0 & $\mathrm{a}$ & 40.7 & $\mathrm{a}$ & 44.5 & $\mathrm{a}$ & 49.7 & $\mathrm{a}$ & 52.9 & $\mathrm{a}$ & 58.5 & $\mathrm{a}$ & 67.7 & $\mathrm{a}$ & 76.8 & $\mathrm{a}$ & 94.4 & $\mathrm{a}$ & 99.5 & $\mathrm{a}$ \\
\hline
\end{tabular}

In a column means with the same letter are not significantly difference at $5 \%$ level by HSD

Table 4: Number of Tillers of IR-28 rice as influenced by different levels of Nitrogen (N) fertilizer application.

\begin{tabular}{|c|c|c|c|c|c|c|c|c|c|c|c|c|c|c|c|c|c|c|}
\hline Tiller No, & 17DAT & & 24DAT & & 31DAT & & 38DAT & & 46DAT & & 52DAT & & 59DAT & & 66DAT & 73DAT & 79DAT & 87DAT \\
\hline No & 5 & $\mathrm{~b}$ & 8 & $\mathrm{c}$ & 8 & $\mathrm{c}$ & 8 & $\mathrm{c}$ & 8 & $\mathrm{c}$ & 9 & $\mathrm{c}$ & 9 & $\mathrm{~b}$ & $9 \mathrm{~b}$ & $10 \mathrm{~b}$ & $10 \mathrm{~b}$ & $10 \mathrm{~b}$ \\
\hline N40 & 9 & $\mathrm{a}$ & 13 & $\mathrm{~b}$ & 14 & $\mathrm{~b}$ & 14 & $\mathrm{~b}$ & 13 & $\mathrm{~b}$ & 13 & $\mathrm{~b}$ & 12 & $\mathrm{a}$ & $11 \quad a b$ & $11 \mathrm{ab}$ & $11 \mathrm{~b}$ & $10 \mathrm{~b}$ \\
\hline N60 & 10 & $\mathrm{a}$ & 14 & $a b$ & 15 & $a b$ & 16 & $\mathrm{ab}$ & 15 & $a b$ & 14 & $a b$ & 14 & $\mathrm{a}$ & $11 \mathrm{a}$ & $12 \mathrm{a}$ & $11 \mathrm{ab}$ & $11 \mathrm{ab}$ \\
\hline N80 & 11 & $\mathrm{a}$ & 17 & $\mathrm{a}$ & 18 & $\mathrm{a}$ & 18 & $\mathrm{a}$ & 17 & $\mathrm{a}$ & 17 & $\mathrm{a}$ & 15 & $\mathrm{a}$ & $12 \mathrm{a}$ & $13 \mathrm{a}$ & $13 \mathrm{a}$ & $12 \mathrm{a}$ \\
\hline
\end{tabular}

In a column means with the same letter are not significantly difference at $5 \%$ level by HSD 


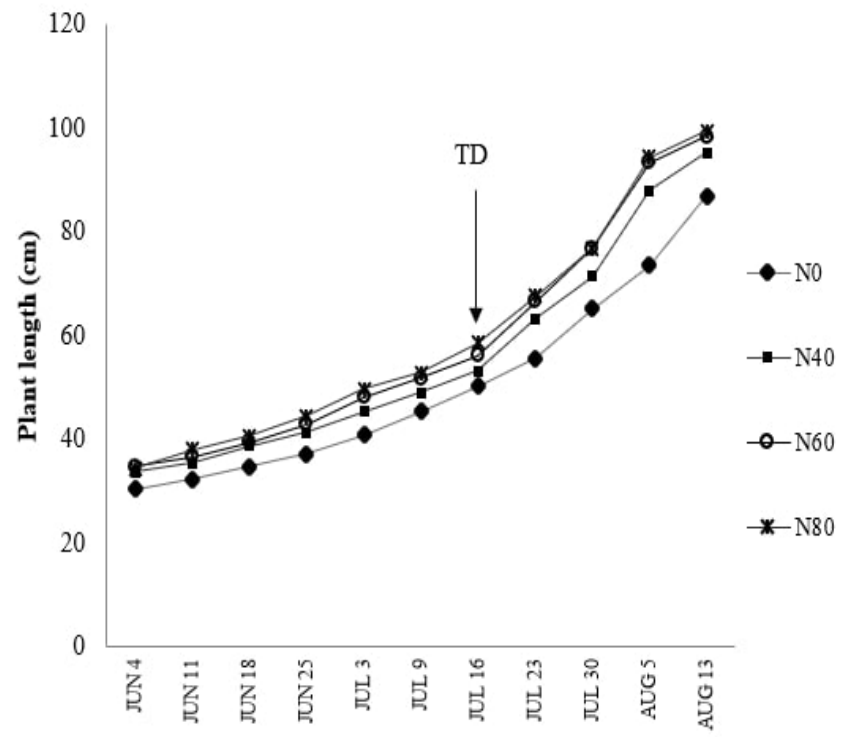

Figure 1. Plant length of rice as influenced by ammonium sulfate fertilizer applications levels. Data presented are means of three replicates. $\mathrm{N} 0=$ No application of $(\mathrm{NH} 4)_{2} \mathrm{SO}_{4}, \mathrm{~N} 40=40 \mathrm{~kg} \cdot \mathrm{ha}^{-1}$ of $(\mathrm{NH} 4)_{2} \mathrm{SO}_{4}, \mathrm{~N} 60=$ $60 \mathrm{~kg} \cdot \mathrm{ha}^{-1}(\mathrm{NH} 4)_{2} \mathrm{SO}_{4}, \mathrm{~N} 80=80 \mathrm{~kg} \cdot \mathrm{ha}^{-1}(\mathrm{NH} 4)_{3} \mathrm{SO}_{4}$

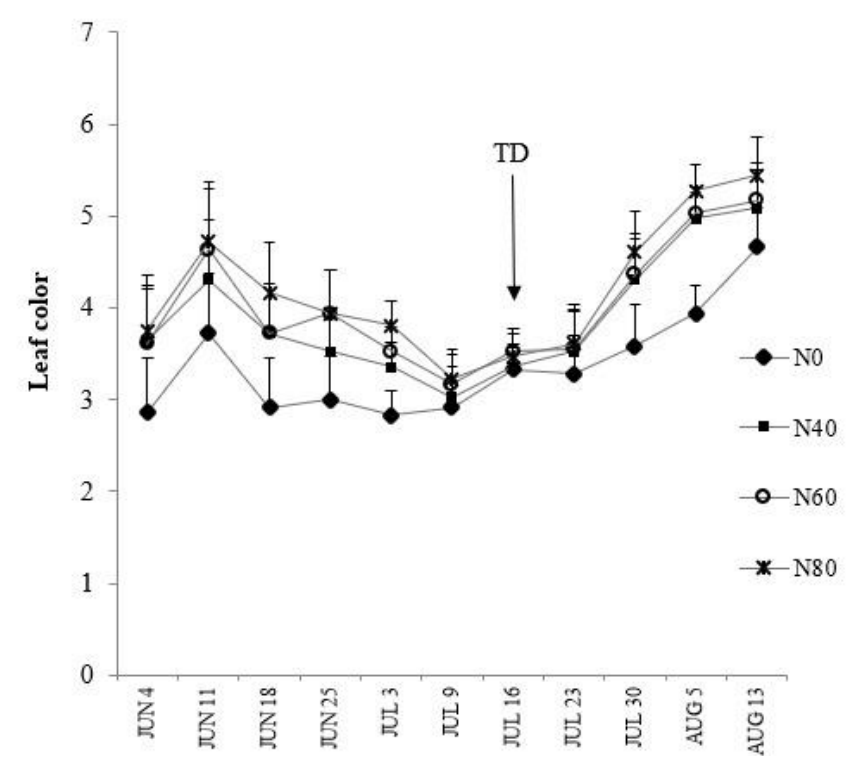

Figure 3. Leaf color of rice as influenced by ammonium sulfate fertilizer applications levels.

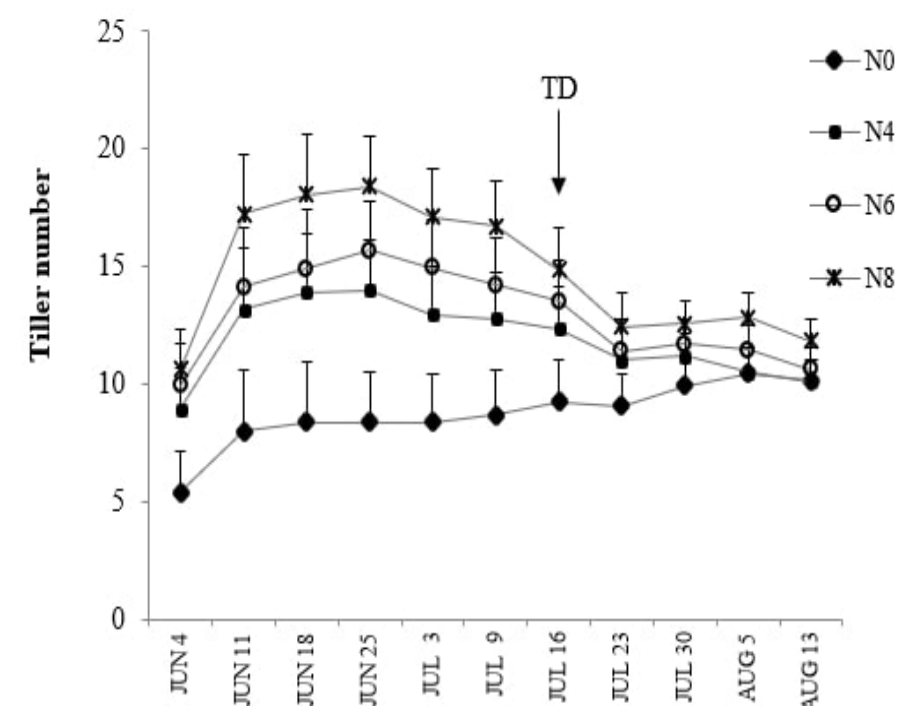

Figure 2. Tiller number of rice as influenced by ammonium sulfate fertilizer applications levels. 
Table 5. Yield and Yield Components of IR-28 rice as affected by different Nitrogen fertilizer levels.

\begin{tabular}{|c|c|c|c|c|c|c|c|c|c|c|}
\hline & $\begin{array}{c}\text { No. of Panicles } \\
\qquad / \mathbf{m}^{2}\end{array}$ & $(\%)$ & $\begin{array}{c}\text { No. of Spikelet/ } \\
\text { panicle }\end{array}$ & $(\%)$ & & $\begin{array}{l}\text { Spikelet } \\
\text { fertility. (\%) } \\
\%\end{array}$ & $\begin{array}{c}1000 \text { grain weight (g) } \\
\text { at } 14 \% \text { Moist }\end{array}$ & $(\%)$ & $\begin{array}{c}\text { Calculated } \\
\text { Yield (ton/ha) }\end{array}$ & $(\%)$ \\
\hline No & 222.22 & $(100) \mathrm{a}$ & 92.61 & (100) & $\bar{a}$ & $84.55 \quad(100) b$ & $25.13 b$ & $(100) \mathrm{b}$ & 4.36 & $\overline{(100) a}$ \\
\hline N40 & 229.62 & (103) a & 89.10 & (96) & $\mathrm{a}$ & $91.16 \quad(108) \mathrm{a}$ & $26.13 a$ & (104) ab & 4.88 & $\overline{(112) a}$ \\
\hline N60 & 266.67 & (120) a & 85.11 & $(92)$ & $\mathrm{a}$ & 90.99 (108) a & $26.08 \mathrm{a}$ & (104) ab & 5.38 & (123) a \\
\hline N80 & 266.67 & (120) a & 85.66 & $\begin{array}{l}(92) \\
\end{array}$ & $\bar{a}$ & $\begin{array}{ll}92.10 & (109) \mathrm{a}\end{array}$ & $27.15 \mathrm{a}$ & (108) a & 5.74 & $\overline{(131) \mathrm{a}}$ \\
\hline
\end{tabular}

Values in the table are means of three replicates. Within a column, means with the same letter do not differ significantly at 0.05 probability level.

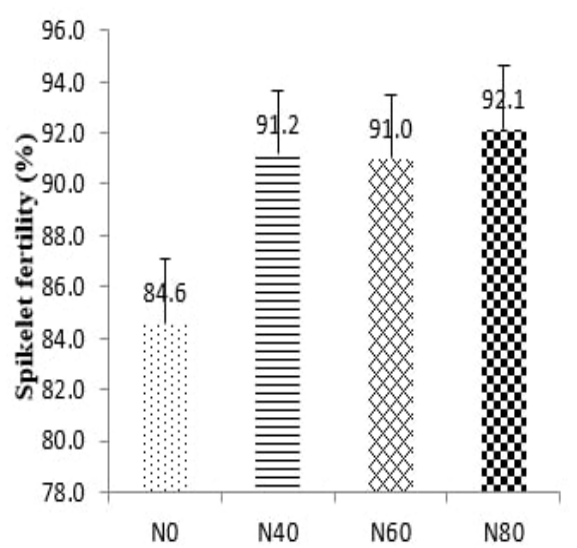

Figure 4. Spikelet fertility as affected by Nitrogen fertilizer levels.

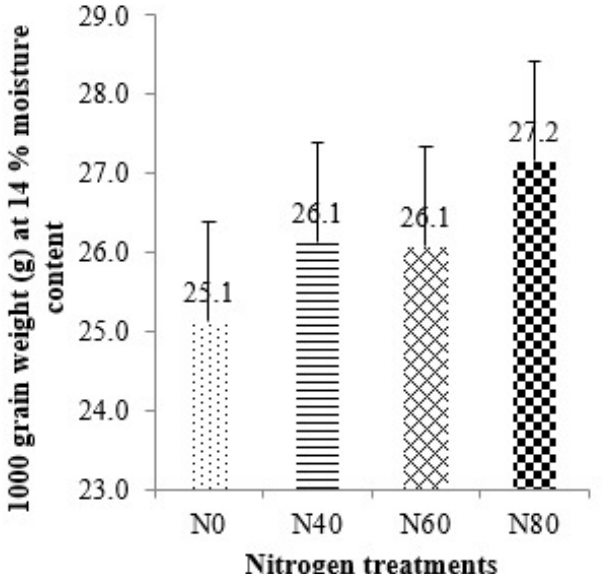

Figure 5. 1000 grain weight of rice at $14 \%$ moisture content as affected by Nitrogen fertilizer levels.

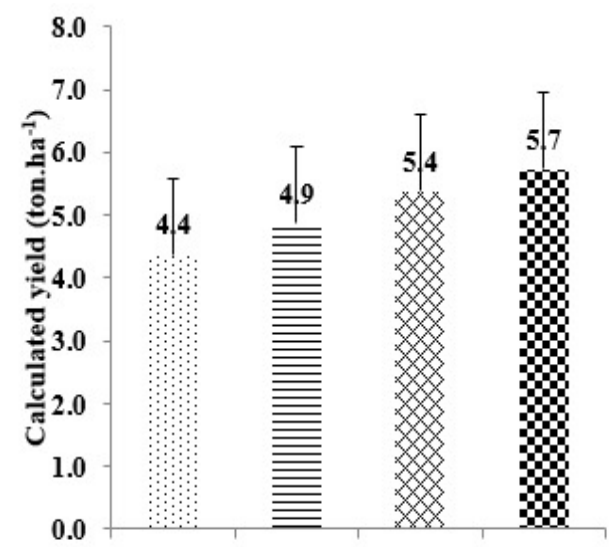

Figure 6. Calculated yield of rice as affected by Nitrogen fertilizer levels. 


\subsection{Growth parameters 4.1.1.Plant length}

4. DISCUSSION

We found that high amounts of Ammonium sulfate fertilizer applications during rice cultivation significantly increase the yield plant length of IR-28 rice. N60 and N80 significantly increased the plant length of rice compared to N0 and N40 (Figure 1). These results were consistent with the findings of Li et al., 2013, that concluded that increased amounts of nitrogen input significantly increased the plant length and basal internode length or rice. The increase in plant length that results from the application of a high amount of nitrogen fertilizer could be explained by the fact that nitrogen is the most important component that supports plant growth. it was previously reported that nitrogen plays a key role in plant development due to the role it plays in the production of chlorophyll, which is crucial for photosynthesis (Munoz-Huerta et al.,2013). Nitrogen has also been reported to be the primary building block for plant protoplasm, which enhances speedy shoot growth.

Some previous studies have reported that nitrogen promotes plant growth and increases the number of internodes and the length of internodes, thus an increase in nitrogen fertilizer application increases the plant length (Gasim, 2001). However, although a high amount of nitrogen fertilizer increased the plant length, it may also cause some unwanted effects on the plant. Previous studies have reported that there is a significant correlation between lodging and plant length (UNAN et al., 2013). Some studies concluded that taller plants may have higher yields, but they may also have a high risk of lodging (Xue et al., 2019). Other studies concluded that a taller rice plant is more susceptible to lodging and to have a poor response to nitrogen (Yoshida, 1978).

\subsubsection{Tiller number}

we found that the highest number of tillers per hill were obtained from high amounts of Ammonium sulfate fertilizer application; N60 and N80 (Figure 2). This result was consistent with numerous previous studies that came to similar conclusions. Cassman et al., 1998, reported that the high yield of rice that Asian farmers are experiencing nowadays is a result of high amounts of nitrogen fertilizer applications. Studies conducted by Yosef in 2012, concluded that high amounts of nitrogen applications increased the tiller number of rice plants. Thieu et al., 2014, also reported that by application of high amounts of nitrogen fertilizer significantly increased the tiller number. The increase in the number of tillers resulting from the application of high nitrogen fertilizer amounts can be explained by the fact that nitrogen $(\mathrm{N})$ is needed to produce chlorophyll which is crucial for photosynthesis (Munoz-Huerta et al.,2013).

However, although high amounts of nitrogen fertilizer increased tiller number, it is worth nothing that, higher quantities of nitrogen fertilizer may enhance the production of non-productive tillers. Previous studies have reported that, increased amounts of nitrogen promoted tiller heterogeneity in rice (Wang et al., 2016). Moreover, the number of productive tillers per plant is one of the most important agronomic traits associated with the grain yields of rice crops (Deng et al., 2020).

\subsubsection{Leaf color}

N40, N60 and N80 significantly increased the leaf colour of the plants compared to the control N0. The likely reason for this observation could be that nitrogen fertilizer applications increased the amount of available nitrogen in the soil which plants absorbed immediately (Figure 3). The leaf colour of the plants helps the farmers know the nitrogen content in the leaves and understand when to apply fertilizer (Tao et al., 2020). Studies have concluded that the level of leaf nitrogen is affected by the rate of nitrogen application (Taylaran et al., 2011). However, for the nitrogen applied to be reflected in the leaf colour, a good root system of the plant is required. The root is the main organ responsible for nitrogen uptake, and root morphology and functioning determine a plant's ability to uptake nitrogen (Jiang et al., 2017; Hu et al., 2018).

\subsection{Yield components}

We found that there were no significant differences among the four treatments in terms of the number of panicles per $\mathrm{m}^{2}$, the number of spikelets per panicles and the calculated yield of IR-28 even though N80 N60 have higher yield values (Figure 6). These results were completely unexpected because several previous studies have reported different findings. Studies concluded that, there was a significant increase of rice yield after applications of high nitrogen amounts (Cassman et al., 2002; Guo et al., 2010). Some other studies concluded that, the high levels of rice yield that is being achieved by Asian farmers nowadays depend on large amounts of nitrogen fertilizers applications (Cassman et al.,2002).

Other previous studies concluded that applying nitrogen topdressing at the panicle initiation stage, as we did in our experiment, significantly increased the number of spikelets per panicles (Ding \& Maruyama, 2004; Kamiji et al., 2011). Nevertheless, these results could be explained by the fact that top dressing was done at panicle initiation stage and fertilizer was not applied at tillering stage. Numerous previous studies have shown that applying nitrogen at the tillering stage of rice increases the number of tillers per hill and consequently the number of panicles per $\mathrm{m}^{2}$, which is the most important component for determining rice yield. Liang et al., 2014, reported that, the more a rice plant could produce tillers, the 
higher its panicle number would be. Similarly, Liao et al., 2019 reported that the tiller number per plant determines the panicle number (Liao et al., 2019).

Also, the number of panicles per $\mathrm{m}^{2}$ was previously reported to be the most important components of rice yield and $87 \%$ of variations in rice yield are caused by the number of panicles (Fageria \& Baligar, 1999). Thus, the non-application of nitrogen fertilizer at tillering stage affected the tillering ability of the plants and subsequently affected the number of panicles per $\mathrm{m}^{2}$, which affected the yield. However, our findings were consistent with some previous studies that concluded that rice grain yield does not increase proportionately with increasing amounts of nitrogen fertilizer (Huang et al., 2007; Huang et al., 2008; Yan et al., 2009).

N40, N60 and N80 significantly increased the spikelet fertility rate (Figure 4) and the 1000 grains weight (Figure 5) of IR 28 rice compared to N0. These results were consistent with numerous previous studies that concluded that, nitrogen is a major determinant in the seed filling process, and its application at panicle initiation stage increases the number of filled spikelets per panicles (Gregersen et al., 2008). Furthermore, studies have reported that, applying nitrogen fertilizer at panicle initiation stage increases the fertility rate of the spikelets, because nitrogen improves photosynthetic capacity and promotes carbohydrates accumulation (Mae, 1997).

\section{CONCLUSION}

The level of nitrogen $(\mathrm{N})$ fertilizer applied during rice cultivation affects the growth and the yield of rice. The plant height and the number of tillers were increased by high levels of nitrogen fertilizers applications. Also, the number of panicles per $\mathrm{m}^{2}$ and the number of spikelets per panicle increased with high amounts of nitrogen fertilizers. By increasing the number of panicles per $\mathrm{m}^{2}$ and the number of spikelets per panicles, high levels of nitrogen fertilizer application subsequently increased the yield of IR-28 rice. Although N80 showed higher calculated yield and yield components than N60, we conclude that N60 is the best nitrogen level to apply for optimum yield of IR-28 because it gives a good yield, and it is more economical than $\mathrm{N} 80$.

\section{CONFLICT OF INTEREST}

The authors have not declared any conflict of interest.

\section{ACKNOWLEDGEMENT}

Japan International Cooperation Agency (JICA)

Ministry of Scientific Research and Innovation (MINRESI) Cameroon.

Institute of Agricultural Research for Development (IRAD)

Mr. WATANABE Tetsu, Mr. MARUYAMA Jumpei and NISHIOKA Miki .

\section{REFERENCES}

Ågren, G. I. (1985). Theory for growth of plants derived from the nitrogen productivity concept. Physiologia plantarum, 64(1), 17-28 https://doi.org/10.1111/j.1399-3054.1985.tb01207.x

Cassman, K. G., Dobermann, A., \& Walters, D. T. (2002). Agroecosystems, nitrogen-use efficiency, and nitrogen management. AMBIO: A Journal of the Human Environment, 31(2), 132-140. https://doi.org/10.1579/0044-744731.2.132

Cassman, K. G., Peng, S., Olk, D. C., Ladha, J. K., Reichardt, W., Dobermann, A., \& Singh, U. (1998). Opportunities for increased nitrogen-use efficiency from improved resource management in irrigated rice systems. Field crops research, 56(1-2), 7-39. https://doi.org/10.1016/S0378-4290(97)00140-8

Deng, R., Jiang, Y., Tao, M., Huang, X., Bangura, K., Liu, C., ... \& Qi, L. (2020). Deep learning-based automatic detection of productive tillers in rice. Computers and Electronics in Agriculture, 177, 105703. https://doi.org/10.1016/j.compag.2020.105703

Ding, Y., \& Maruyama, S. (2004). Proteins and Carbohydrates in Developing Rice Panicles with Different Numbers of Spikelets:Cultivar difference and the effect of nitrogen topdressing. Plant production science, 7(1), 16-21. https://doi.org/10.1626/pps.7.16 
Fageria, N. K., \& Baligar, V. C. (1999). Yield and yield components of lowland rice as influenced by timing of nitrogen fertilization. Journal of Plant Nutrition, 22(1), 23-32. https://doi.org/10.1080/01904169909365603

FAOSTAT, (2008). FAO statistical databases. Available online at htt:/faostat.fao.org/site/342/ default. aspx. Accessed January 2013.

Gasim, S. H. (2001). Effect of nitrogen, phosphorus and seed rate on growth, yield and quality of forage maize (Zea mays L.). Unpublished master thesis), University of Khartoum, Sudan.

Gong, P., Liang, L., \& Zhang, Q. (2011). China must reduce fertilizer use too. Nature, 473(7347), $284-285$. https://doi.org/10.1038/473284e

Gregersen, P. L., Holm, P. B., \& Krupinska, K. (2008). Leaf senescence and nutrient remobilisation in barley and wheat. Plant Biology, 10, 37-49. https://doi.org/10.1111/j.1438-8677.2008.00114.x

Guo, J. H., Liu, X. J., Zhang, Y., Shen, J. L., Han, W. X., Zhang, W. F., ... \& Zhang, F. S. (2010). Significant acidification in major Chinese croplands. science, 327(5968), 1008-1010. https://doi.org/10.1126/science.1182570

Hu, C., Tian, Z., Gu, S., Guo, H., Fan, Y., Abid, M., ... \& Dai, T. (2018). Winter and spring night-warming improve root extension and soil nitrogen supply to increase nitrogen uptake and utilization of winter wheat (Triticum aestivum L.). European journal of agronomy, 96, 96-107. https://doi.org/10.1016/j.eja.2018.03.008

Huang, J. B., Fan, X. H., Zhang, S. L., Ge, G. F., Sun, Y. H., \& Feng, X. (2007). Investigation on the economicallyecologically appropriate amount of nitrogen fertilizer applied in rice production in Fe-leaching-Stagnic Anthrosols of the Taihu Lake region. Acta Ecologica Sinica, 27(2), 588-595. (in Chinese with English abstract)

Huang, J., He, F., Cui, K., Buresh, R. J., Xu, B., Gong, W., \& Peng, S. (2008). Determination of optimal nitrogen rate for rice varieties using a chlorophyll meter. Field Crops Research, 105(1-2), 70-80. https://doi.org/10.1016/j.fcr.2007.07.006

Jiang, S., Sun, J., Tian, Z., Hu, H., Michel, E. J., Gao, J., ... \& Dai, T. (2017). Root extension and nitrate transporter upregulation induced by nitrogen deficiency improves nitrogen status and plant growth at the seedling stage of winter wheat (Triticum aestivum L.). Environmental and Experimental Botany, 141, 28-40. https://doi.org/10.1016/j.envexpbot.2017.06.006

Ju, C., Buresh, R. J., Wang, Z., Zhang, H., Liu, L., Yang, J., \& Zhang, J. (2015). Root and shoot traits for rice varieties with higher grain yield and higher nitrogen use efficiency at lower nitrogen rates application. Field Crops Research, 175, 47-55. https://doi.org/10.1016/j.fcr.2015.02.007

Ju, X. T., Xing, G. X., Chen, X. P., Zhang, S. L., Zhang, L. J., Liu, X. J., ... \& Zhang, F. S. (2009). Reducing environmental risk by improving $\mathrm{N}$ management in intensive Chinese agricultural systems. Proceedings of the National Academy of Sciences, 106(9), 3041-3046. https://doi.org/10.1073/pnas.0813417106

Juan, Y., Chaohu, A. C., Qirong, S., Bin, Y., \& Xinjun, W. (2009). Fertilizer-N uptake and distribution in rice plants using \{ sup 15\} N tracer technique. Acta Agriculturae Nucleatae Sinica, 23. https://www.osti.gov/etdeweb/biblio/21480754

Kamiji, Y., Yoshida, H., Palta, J. A., Sakuratani, T., \& Shiraiwa, T. (2011). N applications that increase plant N during panicle development are highly effective in increasing spikelet number in rice. Field Crops Research, 122(3), 242247. https://doi.org/10.1016/j.fcr.2011.03.016

Kant, S. (2018, February). Understanding nitrate uptake, signaling and remobilisation for improving plant nitrogen use efficiency. In Seminars in Cell \& Developmental Biology(Vol. 74, pp. 89-96). Academic Press. https://doi.org/10.1016/j.semcdb.2017.08.034

Lacroix, A., Beaudoin, N., \& Makowski, D. (2005). Agricultural water nonpoint pollution control under uncertainty and climate variability. Ecological Economics, 53(1), 115-127. https://doi.org/10.1016/j.ecolecon.2004.11.001

Ladha, J. K., \& Reddy, P. M. (2003). Nitrogen fixation in rice systems: state of knowledge and future prospects. Plant and soil, 252(1), 151-167. https://doi.org/10.1023/a:1024175307238

Li, G. H., Zhong, X. H., Tian, K., Huang, N. R., Pan, J. F., \& He, T. H. (2013). Effect of nitrogen application on stem lodging resistance of rice and its morphological and mechanical mechanisms. Scientia Agricultura Sinica, 46(7), 1323-1334. https://en.cnki.com.cn/Article_en/CJFDTotal-ZNYK201307004.htm 
Li, X., Hu, C., Delgado, J. A., Zhang, Y., \& Ouyang, Z. (2007). Increased nitrogen use efficiencies as a key mitigation alternative to reduce nitrate leaching in north china plain. Agricultural Water Management, 89(1-2), 137-147. https://doi.org/10.1016/j.agwat.2006.12.012

Liang, T. A. N. G., XU, Z. J., \& CHEN, W. F. (2017). Advances and prospects of super rice breeding in China. Journal of integrative agriculture, 16(5), 984-991. https://doi.org/10.1016/S2095-3119(16)61604-0

Liang, W. H., Shang, F., Lin, Q. T., Lou, C., \& Zhang, J. (2014). Tillering and panicle branching genes in rice. Gene, 537(1), 1-5. http://hdl.handle.net/20.500.11810/5427

Liao, Z., Yu, H., Duan, J., Yuan, K., Yu, C., Meng, X., ... \& Li, J. (2019). SLR1 inhibits MOC1 degradation to coordinate tiller number and plant height in rice. Nature communications, 10(1), 1-9. https://doi.org/10.1038/s41467-019$10667-2$

Liu, X., Zhang, Y., Han, W., Tang, A., Shen, J., Cui, Z., ... \& Zhang, F. (2013). Enhanced nitrogen deposition over China. Nature, 494(7438), 459-462. https://doi.org/10.1038/NATURE11917

Mae, T. (1997). Physiological nitrogen efficiency in rice: nitrogen utilization, photosynthesis, and yield potential. Plant and soil, 196(2), 201-210. https://doi.org/10.1023/A:1004293706242

Muñoz-Huerta, R. F., Guevara-Gonzalez, R. G., Contreras-Medina, L. M., Torres-Pacheco, I., Prado-Olivarez, J., \& Ocampo-Velazquez, R. V. (2013). A review of methods for sensing the nitrogen status in plants: advantages, disadvantages, and recent advances. sensors, 13(8), 10823-10843. https://doi.org/10.3390/s130810823

Muthayya, S., Sugimoto, J. D., Montgomery, S., \& Maberly, G. F. (2014). An overview of global rice production, supply, trade, and consumption. Annals of the new york Academy of Sciences, 1324(1), 7-14. https://doi.org/10.1111/nyas.12540

Normile, D. (2008). Reinventing rice to feed the world. Science, 321(5887), 330-333. https://doi.org/10.1126/science.321.5887.330

Peng, S., Buresh, R. J., Huang, J., Yang, J., Zou, Y., Zhong, X., ... \& Zhang, F. (2006). Strategies for overcoming low agronomic nitrogen use efficiency in irrigated rice systems in China. Field Crops Research, 96(1), 37-47. https://doi.org/10.1016/j.fcr.2005.05.004

Peng, S., Buresh, R. J., Huang, J., Yang, J., Zou, Y., Zhong, X., ... \& Zhang, F. (2006). Strategies for overcoming low agronomic nitrogen use efficiency in irrigated rice systems in China. Field Crops Research, 96(1), 37-47. https://doi.org/10.1016/j.fcr.2005.05.004

Salvagiotti, F., \& Miralles, D. J. (2008). Radiation interception, biomass production and grain yield as affected by the interaction of nitrogen and sulfur fertilization in wheat. European Journal of Agronomy, 28(3), 282-290. https://doi.org/10.1016/j.eja.2007.08.002

Samonte, S. O. P., Wilson, L. T., Medley, J. C., Pinson, S. R., McClung, A. M., \& Lales, J. S. (2006). Nitrogen utilization efficiency: relationships with grain yield, grain protein, and yield-related traits in rice. Agronomy journal, 98(1), 168176. https://doi.org/10.2134/agronj2005.0180

Stevens, C. J., Dise, N. B., \& Gowing, D. J. (2009). Regional trends in soil acidification and exchangeable metal concentrations in relation to acid deposition rates. Environmental pollution, 157(1), $313-319$. https://doi.org/10.1016/j.envpol.2008.06.033

Tan, Q., Huang, G. H., \& Cai, Y. P. (2011). Radial interval chance-constrained programming for agricultural non-point source water pollution control under uncertainty. Agricultural Water Management, 98(10), 1595-1606. https://doi.org/10.1016/j.agwat.2011.05.013

Tao, M., Ma, X., Huang, X., Liu, C., Deng, R., Liang, K., \& Qi, L. (2020). Smartphone-based detection of leaf color levels in rice plants. Computers and Electronics in Agriculture, 173, 105431 https://doi.org/10.1016/j.compag.2020.105431

Taylaran, R. D., Adachi, S., Ookawa, T., Usuda, H., \& Hirasawa, T. (2011). Hydraulic conductance as well as nitrogen accumulation plays a role in the higher rate of leaf photosynthesis of the most productive variety of rice in Japan. Journal of Experimental Botany, 62(11), 4067-4077. https://doi.org/10.1093/jxb/err126 
Thieu, T. P. T., Yamakawa, T., \& Moe, K. (2014). Effect of nitrogen application timing on growth, grain yield and eating quality of the KD18 and TH3-3 rice varieties. Journal of the Faculty of Agriculture, Kyushu University, 59(1), 5564. https://doi.org/10.5109/1434380

Tian, Z., Li, Y., Liang, Z., Guo, H., Cai, J., Jiang, D., ... \& Dai, T. (2016). Genetic improvement of nitrogen uptake and utilization of winter wheat in the Yangtze River Basin of China. Field Crops Research, 196, 251-260. https://doi.org/10.1016/j.fcr.2016.07.007

ÜNAN, R., Sezer, I., ŞAHIN, M., \& Mur, L. A. (2013). Control of lodging and reduction in plant length in rice (Oryza sativa L.) with the treatment of trinexapac-ethyl and sowing density. Turkish Journal of Agriculture and Forestry, 37(3), 257-264. https://doi.org/10.3906/TAR-1207-72

Wang, Y., Ren, T., Lu, J., Ming, R., Li, P., Hussain, S., ... \& Li, X. (2016). Heterogeneity in rice tillers yield associated with tillers formation and nitrogen fertilizer. Agronomy Journal, 108(4), 17171725. https://doi.org/10.2134/agronj2015.0587

Xue, H., Tian, X., Zhang, K., Li, W., Qi, Z., Fang, Y., ... \& Ning, H. (2019). Mapping developmental QTL for plant height in soybean [Glycine $\max (\mathrm{L}$.$) Merr.] using a four-way recombinant inbred line population. PloS one, 14(11),$ e0224897. https://doi.org/10.1371/journal.pone.0224897

Xun, W., Zhao, J., Xue, C., Zhang, G., Ran, W., Wang, B., ... \& Zhang, R. (2016). Significant alteration of soil bacterial communities and organic carbon decomposition by different long-term fertilization management conditions of extremely low-productivity arable soil in S outh C hina. Environmental microbiology, 18(6), 19071917. https://doi.org/10.1111/1462-2920.13098

Yosef Tabar, S. (2012). Effect of nitrogen and phosphorus fertilizer on growth and yield rice (Oryza sativa L). International journal of agronomy and Plant Production, 3(12), 579-584. Available online at http:// www.ijappjournal.com

Yoshida, S. (1978). Tropical climate and its influence on rice. http://eprints.icrisat.ac.in/id/eprint/8613

Zhang, X., Dong, W., Dai, X., Schaeffer, S., Yang, F., Radosevich, M., ... \& Sun, X. (2015). Responses of absolute and specific soil enzyme activities to long term additions of organic and mineral fertilizer. Science of the Total Environment, 536, 59-67. https://doi.org/10.1016/j.scitotenv.2015.07.043

Zhang, Z., Chu, G., Liu, L., Wang, Z., Wang, X., Zhang, H., ... \& Zhang, J. (2013). Mid-season nitrogen application strategies for rice varieties differing in panicle size. Field Crops Research, 150, 9-18. https://doi.org/10.1016/j.fcr.2013.06.002

Zheng, S., Cao, H., Huang, Q., Liu, M., Lin, X., \& Li, Z. (2016). Long-term fertilization of P coupled with N greatly improved microbial activities in a paddy soil ecosystem derived from infertile land. European Journal of Soil Biology, 72, 14-20. https://doi.org/10.1016/j.ejsobi.2015.12.006

Zhong, X. H., Huang, N. R., \& Zheng, H. B. (2007). Some principles for the "three controls" nutrient management technology for irrigated rice. Guangdong Agric. Sci, 5, 19-22. https://en.cnki.com.cn/Article_en/CJFDTotalGDNY200705005.htm

Zhou, W., Lv, T., Yang, Z., Wang, T., Fu, Y., Chen, Y., ... \& Ren, W. (2017). Morphophysiological mechanism of rice yield increase in response to optimized nitrogen management. Scientific reports, 7(1), 1-10. https://doi.org/10.1038/s41598-017-17491-y

ZHU, D. W., ZHANG, H. C., GUO, B. W., Ke, X. U., DAI, Q. G., WEI, H. Y., ... \& HUO, Z. Y. (2017). Effects of nitrogen level on yield and quality of japonica soft super rice. Journal of integrative agriculture, 16(5), 1018-1027. https://doi.org/10.1016/S2095-3119(16)61577-0 